\title{
Combined Off-Pump Coronary Artery Bypass Grafting and Lung Resection in Patients with Lung Cancer Accompanied by Coronary Artery Disease
}

Ali Yeginsu' ${ }^{1}$, MD; Mustafa Vayvada ${ }^{1}$, MD; Burcin C. Karademir'², MD; Atakan Erkılınç ${ }^{3}$, MD; Ahmet Erdal Tasci' ${ }^{1}$ MD; Fuat Buyukbayrak ${ }^{4}$, MD; Emre Gurcu ${ }^{5}$, MD; Cemal Asım Kutlu' ${ }^{6}$, MD

\begin{abstract}
Introduction: Optimal surgical approach for the treatment of resectable lung cancer accompanied by coronary artery disease (CAD) remains a contentious issue. In this study, we present our cases that were operated simultaneously for concurrent lung cancer and CAD.

Methods: Simultaneous off-pump coronary artery bypass surgery (OPCABG) and lung resection were performed on 10 patients in our clinic due to lung cancer accompanied by CAD. Demographic features of patients, operation data and postoperative results were evaluated retrospectively.

Results: Mean patient age was 63.3 years (range 55-74). All patients were male. Six cases of squamous cell carcinoma, three of adenocarcinoma and one case of large cell carcinoma
\end{abstract}

were diagnosed. Six patients had single-vessel CAD and 4 had two-vessel CAD. Three patients underwent OPCABG at first and then lung resection. The types of resections were one right pneumonectomy, three right upper lobectomies, one right lower lobectomy, three left upper lobectomies, and two left lower lobectomies. Reoperation was performed in one patient due to hemorrhage. One patient developed intraoperative contralateral tension pneumothorax. One patient died due to acute respiratory distress syndrome at the early postoperative period.

Conclusion: Simultaneous surgery is a safe and reliable option in the treatment of selected patients with concurrent CAD and operable lung cancer.

Keywords: Lung Neoplasms. Coronary Artery Disease. Coronary Artery Bypass, Off-Pump.

\begin{tabular}{ll}
\hline \multicolumn{2}{l}{ Abbreviations, acronyms \& symbols } \\
\hline ACT & $=$ Activated clotting time \\
ARDS & $=$ Acute respiratory distress syndrome \\
CABG & $=$ Coronary artery bypass grafting \\
CAD & $=$ Coronary artery disease \\
CPB & $=$ Cardiopulmonary bypass \\
DAPT & $=$ Dual antiplatelet therapy \\
ECG & $=$ Electrocardiogram \\
IMA & $=$ Internal mammary artery
\end{tabular}

'Department of Thoracic Surgery, Kartal Kosuyolu Yuksek Ihtisas Training and Research Hospital, Kartal, Istanbul, Turkey.

${ }^{2}$ Department of Cardiovascular Surgery, Kartal Kosuyolu Yuksek Ihtisas Training and Research Hospital, Istanbul, Turkey.

${ }^{3}$ Department of Anesthesia and Reanimation, Kartal Kosuyolu Yuksek Ihtisas Training and Research Hospital, Istanbul, Turkey.

${ }^{4}$ Department of Cardiovascular Surgery, Okan University School of Medicine, Istanbul, Turkey.

${ }^{5}$ Kartal Kosuyolu Yuksek Ihtisas Training and Research Hospital, Department of Anesthesia and Reanimation, Istanbul, Turkey.

${ }^{6}$ Yuzuncu Yil University School of Medicine Gaziosmanpasa Hospital, Department of Thoracic Surgery, Istanbul, Turkey.
This study was carried out at Kartal Kosuyolu Yuksek Ihtisas Training and Research Hospital, Kartal, Istanbul, Turkey.

No financial support.

No conflict of interest.

Correspondence Address:

Ali Yeginsu

Thoracic Surgery Department

Kartal Kosuyolu Training and Research Hospital, Cevizli/Kartal, Istanbul, Turkey Denizer cd. No:2 34865 - Kartal - Istanbul, Turkey.

E-mail: yeginsu@hotmail.com Article accepted on May 30th, 2018. 


\section{INTRODUCTION}

As the elderly population increases, there are an increasing number of patients who are diagnosed with lung cancer (LC) and have concurrent heart disease requiring surgical intervention. According to The Society of Thoracic Surgeons database, 20.9\% of the patients undergoing pulmonary resection for $\mathrm{LC}$ have coronary artery disease (CAD); however, only $0.4-0.5 \%$ of these patients required coronary artery bypass grafting $(\mathrm{CABG})^{[1-3]}$.

The choice of the ideal surgical procedure is still controversial. Percutaneous coronary intervention $(\mathrm{PCl})$, followed by lung resection, required months of delay in tumor management due to the use of dual antiplatelet therapy (DAPT) and stent thrombosis after cessation of DAPT is the main problem. In staged operations, the cardiac procedure was performed first and after a recovery period of 2 to 8 weeks, pulmonary resection was performed ${ }^{[3]}$. Disadvantages of the staged approach are complications arising from the consequent administration of anesthesia, risk of disease progression due to delayed treatment, patients' anxiety, cost of treatment, hospital stay ${ }^{[3,4]}$. On the other hand, simultaneous procedures have a longer operation time and lead to increased risks of operative bleeding, tissue edema and immunosuppression due to cardiopulmonary bypass $(\mathrm{CPB})^{[3-6]}$.

Off-pump coronary artery bypass grafting (OPCABG) technique has been gaining popularity since the last decade, because it does not require CPB. Recently, several papers showed that simultaneous OPCABG and lung resections may be safe and feasible in combined CAD and $L^{[3,5-8]}$. We presented our patients who underwent simultaneous surgery for concurrent $C A D$ and LC in our clinic.

\section{METHODS}

We retrospectively analyzed patients submitted to simultaneous OPCABG and lung resection from 2014 to 2018. All patients evaluated preoperatively. Respiratory, cardiovascular and other systemic assessments were meticulously performed. All LCs were biopsy-proven and metastatic state was eliminated by positron emission tomography (PET/CT) and cranial magnetic resonance imaging $(\mathrm{MRI})$. If no suspicious mediastinal lymph node was detected on chest CT and PET-CT examinations, preoperative invasive staging was not applied. CAD was evaluated with angiography. All patients were discussed in our multidisciplinary council before the operation.

All patients were operated on electively. CABG was performed at first in 3 patients and then lung resections. Median sternotomy approach was used in all patients. A left anterior thoracotomy was accompanied in one. Patients were heparinized (100-200 U/ $\mathrm{kg}$ ) prior to surgery to adjust the activated clotting time (ACT) between 200-400 seconds. The pericardium was opened. In order to slightly twist the heart counterclockwise and lift it to provide more comfort during the revascularization procedure, deep suspending sutures were placed to the pericardium, taking care not to interfere with the hemodynamic stability. Both the saphenous vein and the left internal mammary artery were prepared as grafts. By suturing the proximal and distal portions of the coronary artery that were anastomosed with 4-0 Prolene, antegrade and retrograde blood flow was blocked. If there were ST and T changes in electrocardiogram (ECG) during the suspension, intracoronary shunt was applied. In order to ensure a stationary anastomosis site, the Octopus III coronary stabilizer was used. After achieving controlled bradycardia via intravenous administration of selective beta-1 blocker (metoprolol tartrate), distal anastomoses were applied using 7-0 Prolene suture. In order to provide a blood-free anastomosis site, a sterile air blower was used. After placing a side clamp in the ascending aorta, proximal anastomoses were made with 5-0 Prolene suture. Following hemostasis, heparin neutralization was provided with protamine at a 1:1.3 ratio.

Selective lymph node dissection (LND) was performed in all patients ${ }^{[9]}$. Stations \#2R and \#4R were dissected for right upper lobe (RUL) tumor and stations \#4, \#5 and \#6 were dissected for left upper lobe (LUL) tumors. Stations \#7, \#8 and \#9 were dissected for lower lobes in both sides. If the intraoperative frozen section study was positive, then systematic LND was performed. Histopathological examination was performed on all surgical resection materials. LC staging was made according to international TNM staging system (primary tumor spread; regional lymph node involvement; intrathoracic or distant metastasis).

After discharge, follow-up visits were scheduled at 3, 6, 12, 18 and 24 months and then every year. All patients were referred to an oncological council after discharge.

\section{RESULTS}

All patients were male, and the mean patient age was 63.3 years (range 55-74). The main patient complaints were difficulty in breathing, chest pain and palpitations. Six cases of squamous cell carcinoma, three of adenocarcinoma and one case of large cell carcinoma were diagnosed. Six patients had single-vessel CAD and four had two-vessel CAD. Seven patients were in stage 1 , two in stage 2 and one in stage 3 . As comorbidity factors, four patients had diabetes mellitus, four hypertension and one had chronic obstructive pulmonary disease (Table 1).

The mean operation time was 292 (range 241-336) minutes. Median sternotomy was performed in all cases. An additional anterior thoracotomy was needed in one patient submitted to left lower lobectomy. Coronary revascularization was performed first in eight of the 10 cases. Left internal mammary artery (IMA) graft was used in six patients and saphenous vein graft was used in four patients (Tables 2 and 3). The mean number of red blood cell suspension transfusions was 1.6 (range 0-4). None of the patients required cardiopulmonary support. Seven patients required inotropic agents.

One right pneumonectomy, three right upper lobectomies, one right lower lobectomy, three left upper lobectomies, and two left lower lobectomies were performed. Additional RUL wedge resections were made for suspicious nodules in the contralateral lung in two patients. Intraoperative frozen section examination indicated benign lesions. No N2 disease was detected by selective LND intraoperatively.

The mean intensive care length of stay was 3.9 days (range 4-7). The mean hospital length of stay was 14.4 days (range 5-19). None of the patients required CPB. We saw four major complications in patients. Bleeding requiring reoperation 
Table 1. Patient demographics.

\begin{tabular}{|c|c|c|c|c|c|c|c|}
\hline Patient & Age & Gender & BMI & Tumor cell type & TNM & Stage & Comorbidity \\
\hline 1 & 62 & $M$ & 24 & Squamous cell carcinoma & T1aNOMO & la & $\mathrm{HT}, \mathrm{COPD}$ \\
\hline 2 & 63 & M & 26 & Adenocarcinoma & T2aNoMo & $\mathrm{Ib}$ & DM \\
\hline 3 & 58 & $M$ & 21 & Adenocarcinoma & T2bNOMO & Ila & HT \\
\hline 4 & 62 & $M$ & 24 & Large cell carcinoma & T3NOMO & $\| \mathrm{ll}$ & $\begin{array}{ll}---- \\
---\end{array}$ \\
\hline 5 & 55 & M & 28 & Squamous cell carcinoma & T1aN0M0 & la & DM \\
\hline 6 & 74 & M & 26 & Squamous cell carcinoma & T1bNOMO & la & DM \\
\hline 7 & 62 & M & 22 & Squamous cell carcinoma & $\mathrm{T} 2 \mathrm{aN} 2 \mathrm{MO}$ & IIla & $\mathrm{DM}, \mathrm{HT}$ \\
\hline 8 & 72 & M & 19 & Squamous cell carcinoma & T3N1M0 & IIla & HT \\
\hline 9 & 68 & M & 28 & Squamous cell carcinoma & T2aNOMO & $1 b$ & ---- \\
\hline 10 & 57 & M & 21 & Adenocarcinoma & T1aNOMO & la & $\begin{array}{ll}---- \\
---\end{array}$ \\
\hline
\end{tabular}

$\mathrm{BMI}=$ body mass index; $\mathrm{COPD}=$ chronic obstructive pulmonary disease; $\mathrm{DM}=$ diabetes mellitus; $\mathrm{HT}=$ hypertension; $M=$ male

Table 2. Operative data of the patients.

\begin{tabular}{|c|c|c|c|c|c|c|}
\hline Patient & $\begin{array}{l}\text { Type of lung } \\
\text { resection }\end{array}$ & CABG vessel & Graft & Incision & Lung resection & $\begin{array}{c}\text { Red blood cells } \\
\text { suspension } \\
\text { (Unit) }\end{array}$ \\
\hline 1 & LUL & Single & SVG & Sternotomy & After OPCABG & 3 \\
\hline 2 & LUL + RULWR & Two & Left IMA & Sternotomy & After OPCABG & 2 \\
\hline 3 & LLL + RULWR & Single & SVG & $\begin{array}{l}\text { Sternotomy + } \\
\text { Left anterior } \\
\text { thoracotomy }\end{array}$ & Before OPCABG & 4 \\
\hline 4 & LLL & Single & SVG & Sternotomy & Before OPCABG & 0 \\
\hline 5 & RUL & Single & SVG & Sternotomy & After OPCABG & 1 \\
\hline 6 & RLL & Single & Left IMA & Sternotomy & After OPCABG & 0 \\
\hline 7 & RUL & Two & Left IMA & Sternotomy & After OPCABG & 1 \\
\hline 8 & $\mathrm{RP}$ & Two & Left IMA & Sternotomy & After OPCABG & 3 \\
\hline 9 & RUL & Single & Left IMA & Sternotomy & After OPCAB & 2 \\
\hline 10 & LUL & Two & Left IMA & Sternotomy & After OPCAB & 0 \\
\hline
\end{tabular}

$C A B G=$ coronary artery bypass grafting; IMA=internal mammary artery; $L L L=$ left lower lobectomy; $L U L=$ left upper lobectomy; $\mathrm{OPCABG}=\mathrm{Off}$-pump coronary artery bypass grafting; $\mathrm{RLL}=$ right lower lobectomy; $\mathrm{RP}=$ right pneumonectomy; RUL=left upper lobectomy; RULWR=right upper lobe wedge resection; SVG=saphenous vein graft

was seen in one patient. Another patient had perioperative tension pneumothorax. We opened the contralateral pleura and introduced a chest tube at the time of closure. One patient suffered from atrial fibrillation on the second day and recovered with antiarrhythmic medication. The last patient presented acute respiratory distress syndrome (ARDS) at the early postoperative period and died due to multiple organ failure 5 days after the operation. Perioperative or postoperative myocardial infarction was not seen. The mean duration of postoperative follow-up was 19.1 months (range 6-35). One patient died in the $35^{\text {th }}$ month of follow-up of tumor dissemination (Table 4).

\section{DISCUSSION}

In combined CAD and LC, treatment options are: 1) $\mathrm{PCl}$ followed by lung resection; 2) staged $C A B G$ and lung resection; 3 ) simultaneous $C A B G$ and lung resection ${ }^{[3]}$. CABG can be performed 
Table 3. Revascularization characteristics of the patients.

\begin{tabular}{c|c|c|c|c}
\hline Patient & CABG vessel & Location & Graft & Anastomosis technique \\
\hline 1 & Single & LAD & SVG & End-to-side \\
\hline 2 & Two & LAD and D1 & LIMA & Sequential technique (D1 - Side-to-side) (LAD - End-to-side) \\
\hline 3 & Single & LAD & SVG & End-to-side \\
\hline 4 & Single & LAD & SVG & End-to-side \\
\hline 5 & Single & OM & SVG & End-to-side \\
\hline 6 & Single & LAD & LIMA & End-to-side \\
\hline 7 & Two & LAD and D1 & LIMA & Sequential technique (D1 - Side-to-side) (LAD - End-to-side) \\
\hline 8 & Two & LAD and D1 & LIMA & Sequential technique (D1 - Side-to-side) (LAD - End-to-side) \\
\hline 9 & Single & LAD & LIMA & End-to-side \\
\hline 10 & Two & LAD and D1 & LIMA & Sequential technique (D1 - Side-to-side) (LAD - End-to-side) \\
\hline
\end{tabular}

$C A B G=$ coronary artery bypass grafting; $L A D=l$ eft anterior descending artery; $D 1=$ first diagonal arterial branch of $L A D ; L I M A=l$ eft internal mammary artery; SVG=saphenous vein graft; $\mathrm{OM}_{1}=$ obtuse marginal artery

Table 4. Postoperative results.

\begin{tabular}{|c|c|c|c|c|c|}
\hline Patient & ICU stay (days) & $\begin{array}{l}\text { Hospital stay } \\
\text { (days) }\end{array}$ & Complication & Mortality & Survival \\
\hline 1 & 2 & 16 & ---- & Dead & 35 months \\
\hline 2 & 5 & 5 & ARDS, multiorgan failure & Dead & 5 day \\
\hline 3 & 2 & 19 & ---- & Alive & 30 months \\
\hline 4 & 4 & 18 & - & Alive & 6 months \\
\hline 5 & 7 & 13 & Reoperation for bleeding & Alive & 28 months \\
\hline 6 & 4 & 17 & ---- & Alive & 27 months \\
\hline 7 & 4 & 11 & ---- & Alive & 25 months \\
\hline 8 & 5 & 12 & $\begin{array}{l}\text { Perioperative tension } \\
\text { pneumothorax }\end{array}$ & Alive & 20 months \\
\hline 9 & 2 & 14 & ---- & Alive & 6 months \\
\hline 10 & 4 & 19 & Atrial fibrillation & Alive & 9 months \\
\hline
\end{tabular}

ARDS=adult respiratory distress syndrome; ICU=intensive care unit

with or without CPB. Regarding the treatment of these patients, each technique has its own advantages and disadvantages.

Balloon angioplasty with stent placement is a safe and effective method, but it has not been recommended for patients with left main CAD and with three-vessel disease. It has increased risk of operative bleeding related to the use of antithrombotic medication ${ }^{[7,10,11]}$. Timing of cancer surgery is debatable due to stent thrombosis after cessation of DAPT. At least, 3 month delay between $\mathrm{PCl}$ and lung resection has been recommended ${ }^{[6,12]}$. Fernandez et al. ${ }^{[13]}$ showed increased perioperative thrombosis or myocardial infarction and mortality in patients with stents compared to non-stent patients. Stent placement in the 12 months prior to surgery significantly increased 30-day cardiac events (9.3\%) and mortality (7.7\%).
The use of CPB in CABG is still a great dilemma due to its side effects such as: increased surgical bleeding, triggering the systemic inflammatory response syndrome; increased capillary bed permeability; and pulmonary edema, leading to impairment in immune system ${ }^{[3-6]}$. The purpose of the OPCABG is to protect physiological systems from adverse effects resulting from the use of CPB and related methods. Performing myocardial revascularization while the heart is still beating helps to reduce postoperative complications and immunosuppression ${ }^{[14]}$. Avoidance of CPB results in reduced pulmonary function disturbances, decreased incidence of postoperative atrial fibrillation, and reduced need for blood transfusion, perioperative intra-aortic balloon pump and possible tumor cell dissemination ${ }^{[15,16]}$. 
Table 5. Outcomes of simultaneous OPCABG and lung tumor resection in the literature.

\begin{tabular}{|c|c|c|}
\hline Author, study & Outcomes & Conclusion \\
\hline $\begin{array}{l}\text { - Saxena et al. }{ }^{[8]} \\
\text { - Cohort study (2004) } \\
\text { - Six patients underwent OPCABG and LR } \\
\text { between } 2000-2004 \\
\text { - Mean age was } 67.6 \text { years (58-75) } \\
\text { - Single- to 3-vessel CAD and stage 1-2 } \\
\text { tumors }\end{array}$ & $\begin{array}{l}\text { - Patients were followed up for } 9 \text { months to } \\
3 \text { years } \\
\text { - Prolonged airleak and pleural space in } 2 \\
\text { patients } \\
\text { - No CAD recurrence } \\
\text { - No early mortality } \\
\text { - Late mortality: } 2 / 6 \text { patients ( } 33 \%) \\
\text { - Mean hospital stay: } 12.5 \text { days }\end{array}$ & $\begin{array}{l}\text { - Authors concluded that combined } \\
\text { surgery is a safe approach in } \\
\text { patients with concomitant CAD and } \\
\text { lung cancer }\end{array}$ \\
\hline $\begin{array}{l}\text { - Schoenmakers et al. }{ }^{[6]} \\
\text { - Cohort study (2007) } \\
\text { - } 28 \text { patients underwent CABG and } 15 \\
\text { underwent OPCABG and LR between } \\
\text { 1994-2005 } \\
\text { - Mean age was } 66 \text { years in CABG group } \\
\text { and } 71 \text { years in OPCABG group } \\
\text { - Single- to 3-vessel CAD and stage 1-3 } \\
\text { tumors }\end{array}$ & $\begin{array}{l}\text { - Hospital mortality was } 2 \% \text { in } C A B G \text { and } 1 \% \\
\text { in OPCABG group }(P<0.05) \text {. } \\
\text { - Reexploration, cardiac and pulmonary } \\
\text { complications. } \\
\text { - There were more pulmonary complications } \\
\text { in the CABG group }(P=0.04) \text {. } \\
\text { - Mean survival was } 5.25 \text { years in CABG group } \\
\text { and } 3 \text { years in OPCABG group ( } P=0.09) \\
\text { - Two- and } 5 \text {-year survival rates are } 64 \% \text { and } \\
\text { 46\% in CABG group and } 47 \% \text { and } 13 \% \text { in } \\
\text { OPCABG group ( } P<0.01) \text {. } \\
\text { - Mean hospital stay was } 14 \text { days in CABG } \\
\text { group and } 12 \text { days in OPCABG group } \\
\end{array}$ & $\begin{array}{l}\text { - Authors believe that the results } \\
\text { of their study did not show } \\
\text { evidence that OPCABG is a superior } \\
\text { treatment to CABG in patients } \\
\text { with combined cardiac and lung } \\
\text { pathology } \\
\text { - On the other hand, OPCABG group } \\
\text { has fewer and older patients. And } \\
\text { they have more advanced lung } \\
\text { cancer, therefore more studies were } \\
\text { needed for evaluation }\end{array}$ \\
\hline $\begin{array}{l}\text { - Dyszkiewicz et al. }{ }^{[2]} \\
\text { - Cohort study (2008) } \\
\text { - } 25 \text { patients underwent combined } \\
\text { OPCABG and LR from } 2001 \text { to } 2006 \\
\text { - Mean age was } 63 \text { years (57-75) } \\
\text { - Majority of patients have 2-vessel CAD } \\
\text { and stage 1-3 tumors } \\
\text { - } 13 \text { patients had undergone PCl and/or } \\
\text { stent implantation before lung cancer } \\
\text { was diagnosed }\end{array}$ & $\begin{array}{l}\text { - Patients were followed up for } 8 \text { months to } \\
5 \text { years } \\
\text { - No perioperative death and new Ml } \\
\text { - Rethoracotomy in } 1 \text { patient, atrial fibrillation } \\
\text { in 6, atelectasis in 3, prolonged airleak in 3, } \\
\text { bronchopleural fistula in } 1 \\
\text { - 3-year survival was } 50 \% \\
\text { - Recurrence of cancer was } 55 \% \text { and was the } \\
\text { only statistically significant factor with an } \\
\text { impact on survival ( } P<0.01 \text { ) } \\
\text { - Mean hospital stay was } 8 \text { days (6-28) }\end{array}$ & $\begin{array}{l}\text { - Combined surgery is a safe and } \\
\text { effective treatment in patients with } \\
\text { concomitant unstable CAD and } \\
\text { lung cancer } \\
\text { - According to the author, combined } \\
\text { surgery requires different surgical } \\
\text { skills }\end{array}$ \\
\hline $\begin{array}{l}\text { - Ma et al. }{ }^{[7]} \\
\text { - Cohort study (2016) } \\
\text { - } 34 \text { patient underwent combined OPCABG } \\
\text { and LR from } 2003 \text { to } 2014 \\
\text { - Mean age was } 65 \text { years (54-77) } \\
\text { - First OPCABG was performed and then LR } \\
\text { - Single- to 3-vessel CAD and stage 1-3 } \\
\text { lung cancer patients }\end{array}$ & $\begin{array}{l}\text { - Patients were followed up for } 5 \text { to } 60 \\
\text { months } \\
\text { - No perioperative death } \\
\text { - No perioperative Ml } \\
\text { - Two patients had lung infection, } 3 \text { had } \\
\text { atelectasis and } 5 \text { had arrhythmias } \\
\text { - Three- and } 5 \text {-year mortality were } 75 \text { and } \\
67 \%, \text { respectively } \\
\text { - Recurrence occured in } 7 \text { patients } \\
\text { - Mean hospital stay was } 17 \pm 6 \text { days } \\
\end{array}$ & $\begin{array}{l}\text { - Combined OPCABG and LR is a safe } \\
\text { and effective treatment option with } \\
\text { good long-term survival rates } \\
\text { - Additionally, this procedure is a safe } \\
\text { option in patients with 3-vessel } \\
\text { CAD who are not candidates for PCI }\end{array}$ \\
\hline $\begin{array}{l}\text { - Yeginsu et al. (present article) } \\
\text { - Cohort study (current) } \\
\text { - } 10 \text { patients underwent combined } \\
\text { OPCABG and LR from } 2014 \text { to } 2018 \\
\text { - Mean age was } 63 \text { (55-74) years } \\
\text { - Single to } 2 \text { vessel CAD and stage 1-2 lung } \\
\text { cancer patients }\end{array}$ & $\begin{array}{l}\text { - Patients were followed up for } 6 \text { to } 35 \\
\text { - } \text { months } \\
\text { - No operative death } \\
\text { - One patient (10\%) died in early and } 1 \text { (10\%) } \\
\text { died in the late postoperative period } \\
\text { - Major complications were bleeding, ARDS, } \\
\text { tension pneumothorax and atrial fibrillation } \\
\text { - Mean hospital stay was } 14.4 \text { days (5-19) }\end{array}$ & $\begin{array}{l}\text { Combined OPCABG and LR is a } \\
\text { safe and reliable surgical method; } \\
\text { however, data is not sufficient } \\
\text { to conclude that it is the best } \\
\text { approach for the patient with } \\
\text { concomitant CAD and lung cancer }\end{array}$ \\
\hline
\end{tabular}

ARDS=adult respiratory distress syndrome; $C A B G=$ coronary artery bypass grafting; $C A D=$ coronary artery disease; $O P C A B G=0$ ff-pump coronary artery bypass grafting; $\mathrm{LR}=$ lung resection; $\mathrm{Ml}=$ myocardial infarction; $\mathrm{PCl}=$ percutaneous coronary intervention 
Patients undergoing simultaneous surgery with CPB present complications and mortality rates significantly higher than those expected in staged procedures ${ }^{[3,5]}$. Bleeding rate is between $0-16 \%{ }^{[3]}$ and the infectious complications are about $14 \%{ }^{[17]}$ in CPB used in simultaneous surgery. Operative mortality, 1- and 5-year survival were $0-20.8 \%, 79-100 \%$ and $34.9-85 \%$, respectively, in patients undergoing simultaneous surgery, while 0-10\%, $72.7 \%$ and $53 \%$, respectively, in patients undergoing staged surgery ${ }^{[3,5]}$. On the other hand, OPCABG has been shown to be a safe and reliable method for simultaneous surgery ${ }^{[3,5-8]}$ (Table 5). Bleeding risk and mortality ranged from 0 to $8 \%$ and 0 to $6.6 \%$, respectively. Five-year survival was 13 to $68 \%{ }^{[3,5]}$. In our patients, bleeding rate and operative mortality occur in one (10\%) patient.

In technical aspects of simultaneous operations, choice of procedural approach, timing and sequence of surgical steps, and adequacy of procedure for tumor surgery are important issues.

Median sternotomy should be the standard approach for simultaneous heart and lung operations ${ }^{[2-5,8]}$. Compared to posterolateral thoracotomy, pulmonary dysfunction and postoperative pain are lower with median sternotomy. However, sternotomy may be inefficient to provide an adequate field of vision for lung resections. The process of dissection and traction of the heart may lead to arrhythmias and hemodynamic instability, especially for tumors localized to left lower lobe. By opening the right pleura and pericardium and pushing the heart to the right side, a better field of vision may be accomplished. Single-lung ventilation, complete mobilization of the lung and myocardial revascularization in the first place may facilitate this maneuver ${ }^{[18,19]}$. An additional left anterior thoracotomy and/ or thoracoscopic assistance are very helpful for an adequate exposure. We performed sternotomy plus anterior thoracotomy in one patient with left lower lobe tumor and we found no difficulty during resection.

The main goal of a simultaneous operation in patients with lung tumor and CAD should be to avoid myocardial ischemia during lung resection. Therefore, OPCABG should be performed first rationally ${ }^{[7]}$. However, it is recommended that lung resection should be performed first when CPB is used ${ }^{[5]}$. In addition, some technical difficulties, such as tumor size and location, dense pleural adhesions, use of both IMAs, may require lung resection first. We performed lung resection first in two patients because the tumors located centrally in left lower lobe and there were dense pleural adhesions and we concerned about injuring the grafts when we resected the lobes.

Another important aspect in LC surgery with median sternotomy is the adequate dissection of mediastinal and hilar lymph nodes. Single-lung ventilation, dividing inferior pulmonary ligament and intrapleural liberation, may help to achieve an adequate field of vision for LND. With sternotomy, hilar, interlobar, lobar, segmental and inferior pulmonary lymph nodes at both mediastinal, and subcarinal lymph nodes on the left side may be sampled ${ }^{[8]}$. Although systematic LND is recommended ${ }^{[20]}$, selective $L N D$ is also an acceptable option in LC surgery for adequate tumor cleaning and staging for stage 1 and 2 tumors ${ }^{[9]}$. The reported possible advantage of selective LND is reducing the hospital stay, but its reliability and applicability are still unclear. Multi-institutional randomized clinical trials are needed to answer the question of which is the best option.

\section{CONCLUSION}

In conclusion, simultaneous lung resections and OPCABG in patients with $C A D$ accompanying $L C$ is a safe and reliable surgical method. Several authors reported that it presented less morbidity and mortality compared to other options using CPB. Long-term survival is comparable in the others. On the other hand, data are not sufficient to conclude that combined OPCABG and lung resection are the best approach for the patient with concomitant LC and CAD. We need larger randomized studies for certainty.

\section{Authors' roles \& responsibilities}

AY

Substantial contributions to the conception or design of the work; or the acquisition, analysis, or interpretation of data for the work; drafting the work or revising it critically for important intellectual content; final approval of the version to be published; final approval of the version to be published

MV Drafting the work or revising it critically for important intellectual content; final approval of the version to be published; final approval of the version to be published

BCK Substantial contributions to the conception or design of the work; or the acquisition, analysis, or interpretation of data for the work; final approval of the version to be published

Final approval of the version to be published

AE Agreement to be accountable for all aspects of the work in AET ensuring that questions related to the accuracy or integrity of any part of the work are appropriately investigated and resolved; final approval of the version to be published

Final approval of the version to be published

FB Drafting the work or revising it critically for important EG intellectual content; final approval of the version to be published

CAK

Substantial contributions to the conception or design of the work; or the acquisition, analysis, or interpretation of data for the work; final approval of the version to be published

\section{REFERENCES}

1. Kozower BD, Sheng S, O'Brien SM, Liptay MJ, Lau CL, Jones DR, et al. STS database risk models: predictors of mortality and major morbidity for lung cancer resection. Ann Thorac Surg. 2010;90(3):875-81.

2. Dyszkiewicz W, Jemielity M, Piwkowski C, Kasprzyk M, Perek B, Gasiorowski L, et al. The early and late results of combined off-pump coronary artery bypass grafting and pulmonary resection in patients with concomitant lung cancer and unstable coronary heart disease. Eur J Cardiothorac Surg. 2008;34(3):531-5. 
3. Powell B, Bolton WD. Management of lung cancer with concomitant cardiac disease. Thorac Surg Clin. 2018;28(1):69-79.

4. Urschel HC Jr, Razzuk MA. Median sternotomy as a standard approach for pulmonary resection. Ann Thorac Surg. 1986;41(2):130-4.

5. Tourmousoglou CE, Apostolakis E, Dougenis D. Simultaneous occurrence of coronary artery disease and lung cancer: what is the best surgical treatment strategy? Interact Cardiovasc Thorac Surg. 2014;19(4):673-81.

6. Schoenmakers MC, van Boven WJ, van den Bosch J, van Swieten HA. Comparison of on-pump or off-pump coronary artery revascularization with lung resection. Ann Thorac Surg. 2007;84(2):504-9.

7. Ma X, Huang F, Zhang Z, Song F, Ou S. Lung cancer resection with concurrent off-pump coronary artery bypasses: safety and efficiency. J Thorac Dis. 2016;8(8):2038-45.

8. Saxena P,Tam RK. Combined off-pump coronary artery bypass surgery and pulmonary resection. Ann Thorac Surg. 2004;78(2):498-501.

9. Han $\mathrm{H}$, Chen $\mathrm{H}$. Selective lymph node dissection in early-stage nonsmall cell lung cancer. J Thorac Dis. 2017;9(7):2102-7.

10. Hernández JM, Fernández JF, Tenas MS, Ruigómez JG. Update on interventional cardiology. Rev Esp Cardiol. 2012;65(Suppl 1):4-11.

11. Kałuza GL, Joseph J, Lee JR, Raizner ME, Raizner AE. Catastrophic outcomes of noncardiac surgery soon after coronary stenting. J Am Coll Cardiol. 2000;35(5):1288-94.

12. Chassot PG, Delabays A, Spahn DR. Preoperative evaluation of patients with, or at risk of, coronary artery disease undergoing non-cardiac surgery. Br J Anaesth. 2002;89(5):747-59.

13. Fernandez FG, Crabtree TD, Liu J, Meyers BF. Incremental risk of prior coronary arterial stents for pulmonary resection. Ann Thorac Surg. 2013;95(4):1212-8.

14. Wu M, Lu Y, Chen R, Zhou H. Changes in phospholipase D activity of leukocytes during human systemic inflammatory response syndrome induced by cardiopulmonary bypass. Chin Med J. 2003;1 16(6):873-7.

15. Hasegawa S, Otake Y, Bando T, Cho H, Inui K, Wada H. Pulmonary dissemination of tumor cells after extended resection of thyroid carcinoma with cardiopulmonary bypass. J Thorac Cardiovasc Surg. 2002;124(3):635-6.

16. Patanè F, Verzini A, Zingarelli E, di Summa M. Simultaneous operation for cardiac disease and lung cancer. Interact Cardiovasc Thorac Surg. 2002;1(2):69-71.

17. Brutel de la Rivière A, Knaepen P, Van Swieten H, Vanderschueren R, Ernst J, Van den Bosch J. Concomitant open heart surgery and pulmonary resection for lung cancer. Eur J Cardiothorac Surg. 1995;9(6):310-3.

18. Tschernko EM, Bambazek A, Wisser W, Partik B, Jantsch U, Kubin K, et al. Intrapulmonary shunt after cardiopulmonary bypass: the use of vital capacity maneuvers versus off-pump coronary artery bypass grafting. J Thorac Cardiovasc Surg. 2002;124(4):732-8.

19. Cleveland JC Jr, Shroyer AL, Chen AY, Peterson E, Grover FL. Off-pump coronary artery bypass grafting decreases risk-adjusted mortality and morbidity. Ann Thorac Surg. 2001;72(4):1282-8.

20. Howington JA, Blum MG, Chang AC, Balekian AA, Murthy SC. Treatment of stage I and II non-small cell lung cancer: Diagnosis and management of lung cancer, 3rd ed: American College of Chest Physicians evidencebased clinical practice guidelines. Chest. 2013;143(5 Suppl):e278S-e313S. 